\title{
Appraisal of growth, development, yield and quality of Solanum melongena to different growth condition
}

\author{
Umaira Shahid ${ }^{1,2}$, Kamran Shah",3*, Imran Ahmed ${ }^{2}$, Noor ul Amin ${ }^{2}$, \\ Gulshan $\mathrm{Ara}^{4}$, Sana Irshad Khan ${ }^{5}$, Gul Guttai ${ }^{6}$ and Bibi Zainub ${ }^{2}$ \\ 1. Agriculture Research Institute Tarnab, Peshawar, Pakistan \\ 2. Department of Horticulture, The University of Agriculture Peshawar-Pakistan \\ 3. College of Horticulture, Northwest Agriculture and Forestry University, Yangling 712100, Shaanxi-China \\ 4. Institute of Biotechnology and Genetic Engineering, The University of Agriculture, Peshawar-Pakistan \\ 5. Section of Soil Chemistry, Directorate of Soil and Plant Nutrition, Agriculture Research Institute Tarnab, \\ Peshawar-Pakistan \\ 6. Agriculture Extension Department, Khyber Pakhtunkhwa-Pakistan \\ *Corresponding author's email: kamranshah801@nwafu.edu.cn ; kamranshah801@gmail.com \\ Citation \\ Umaira Shahid, Kamran Shah, Imran Ahmed, Noor ul Amin, Gulshan Ara, Sana Irshad Khan, Gul Guttai, Bibi \\ Zainub. Appraisal of growth, development, yield and quality to different growth condition in Solanum melongena. \\ Pure and Applied Biology. Vol. 8, Issue 2, pp1861-1875. http://dx.doi.org/10.19045/bspab.2019.80130

\begin{tabular}{llll}
\hline \hline Received: 15/03/2019 & Revised: 19/06/2019 & Accepted: 24/06/2019 & Online First: 27/06/2019 \\
\hline
\end{tabular}

\section{Abstract}

Commercial organic production of brinjal is a challenge for growers, which links to understand the field trail of organic and inorganic regime on its growth, yield and development. Current experiment was conducted in Randomized Complete Block Design with split plot arrangements and three times replicated. Organic regime (Farm Yard Manure, Spent Mushroom Compost and Poultry Manure at 25:10:5 tons $\mathrm{ha}^{-1}$ ) and Inorganic regime (N:100, P:50, K:50 kg ha-1) were assigned to the main plots while brinjal cultivars (Namli-F1, Black Boy-F1, BSS-513 and Meiyinqienquan) were subjected to the subplots. Data on various quantitative and qualitative variables of eggplant cultivars were taken under both the regimes. Results revealed that both cultivars and growing regimes significantly $(\mathrm{p} \leq 0.05)$ affected the performance of eggplant. Among eggplant cultivars, more number of leaves, fruits, fruit weight plant $^{-1}$ and total yield were observed in cultivar Namli-F1 followed by Black boy-F1 which also gave maximum total soluble solids. Highest plant height and fruit dry matter contents were noted in cultivar BSS-513. However, the performance of cultivar Meiyinqienquan was inferior among all the cultivars except for the number of days to 50\% flowering. Regarding growing regimes, it was noticed that under the organic regime maximum plant height, number of fruits, fruit weight plant $^{-1}$, total yield and total soluble solids were produced. Whereas, maximum number of leaves plant ${ }^{-1}$ and chlorophyll content were produce under the inorganic regime. Present investigations concluded that cultivar Namli-F1 should be grown for the promising yield while Black boy-F1 and BSS513 for their better quality under the organic regime.

Keywords: Brinjal; Growth; Inorganic; Organic; Yield 


\section{Introduction}

Eggplant is botanically called Solanum melongena L. a well-known specie of Solanaceae (Night Shade) family. It is known as brinjal, garden egg or aubergine [1]. It is an important annual herb of subtropics and perennial of tropics, woody at the base [2]. The shape of the fruit of some of its white verities are similar with the shape of a chicken egg, so the name eggplant is given [3] having wide variation in fruit size, shape and color [4]. Eggplant is believed to be originated in the Indo-Burma region [5]. It is a versatile crop, adapted to a wide range of agro-climatic regions of the world [6]. In KP, eggplant is cultivated on 1.32 thousand hectares area out of 9.04 thousand hectares with the estimated production of about 13.65 thousand tons out of 91.13 tones of Pakistan [7].

[8] analyzed that fresh eggplant fruit (100 gm) contain sufficient quantity of moisture $(92.7 \%)$, carbohydrates (4.0 gm), protein (1.4 gm), fat (0.3 gm), vitamin C (12 mg), calcium $(18 \mathrm{mg})$, iron $(0.9 \mathrm{mg})$, thiamine $(0.04 \mathrm{mg})$ and riboflavin $(0.11 \mathrm{mg})$. In addition, it's also a rich source of copper, vitamin-B, niacin, folate, and dietary fiber [9]. Its fruit is used primarily for cooking purpose and a raw material for dehydration and pickle making industries [10]. It prevents constipation and helps in digestion due to its roughage value. Also used as a cure for toothache while white fruits are recommended for diabetic patients [11].

A long warm season with a temperature of about $25-32^{\circ} \mathrm{C}$ day and $21-27^{\circ} \mathrm{C}$ night is suitable for the successful production of eggplant. It grows on an open range of soil types however performs best on a well drained silty or clay loam soil having $\mathrm{pH}$ of 5.5- 6.5 [12]. Many reviews showed that eggplant performed well with the application of NPK fertilizers [13]. Nitrogen (N) is a major component of all amino acids (protein), lipids and chloroplasts [14]. Fruit
$\mathrm{pH}$, total soluble solids, crude protein, vitamin $\mathrm{C}$, seed number, delayed in flowering and fruit setting in eggplant is significantly affected by increasing nitrogen fertilizers [15]. Phosphorus (P) is a second macronutrient, a major constituent of nucleic acids, energy compounds (ATPs and ADPs), co-enzymes, phospholipids and plays important role in promoting plant growth, early and total yield [16]. It has positive impact on root system, helps in formation of fibrous, lateral and healthy roots [17] accelerate maturity, resistance to disease, protein levels, palatability of fruit, in seeds lowering its fat contents and also balancing other nutrients in eggplant [18]. Potassium $(\mathrm{K})$ is a third essential macronutrient and its major role is in translocation of assimilates, protein synthesis, improves fruit quality and enhancing of enzymatic activity inside plant body [19].

Application of inorganic fertilizers in excess create problems like increase losses of fertilizers, soil erosion, environmental pollution, pest resistance and food chain restriction that ultimately affected human health while organic fertilizers provide healthy and qualitative foods by supplying essential nutrients to plant [20]. Organic matter increases soil fertility, anion and cation exchange capacity, soil microbial activity, soil structure, soil $\mathrm{pH}$, organic and carbon content of soil and thus enhance fruit quality and yield [21]. Organic manures like Farmyard and poultry manure are most frequently used in developing countries including Pakistan for obtaining better crops yield and quality [22]. FYM acts as soil conditioner, supply all the essential nutrients required for the growth of plant [23] activates soil microbial colony by slowly release of nutrients [24]. Poultry manure (PM) is an excellent soil amendment and natural fertilizer, possess high organic nitrogen content [25] phosphorus, potassium and other essential plant nutrients [26] 
maintaining and establishing physical condition of soil, proper plant growth, resistant to microbial degradation, nutrients and moisture holding capacity due to its bulky nature thus helping in the sustainable production of crops [27]. Spent mushroom compost (SMC) is a good soil conditioner, increasing dry matter production, availability of plant essential nutrients, organic matter contents and improving soil structure [28].

Eggplant is a high yielding vegetable in the local market and an important source of income for the local farmers and trade [29]. Composition of eggplant is influenced by growing conditions, techniques, and genetic diversity of cultivars used [30]. This study assessed variability of growth, quality and yield among the hybrid cultivars of brinjal as affected under the organic and inorganic regimes. Hybrids have the ability to produce higher yield. There are number of variations among the hybrid cultivars of eggplant such as earliness, color of fruit skin, fruiting period length. In view of the above facts, the potent work was aimed with the objectives to evaluate the best performing hybrid cultivar of eggplant under the organic and inorganic regime and to specify the optimum regime for the improved quantitative and qualitative attributes of eggplant cultivars.

\section{Materials and methods \\ Experimental site}

Experimental site of current experiment is located at $34.0167^{\circ} \mathrm{N}$ latitude and 71.5833 ${ }^{\circ} \mathrm{E}$ longitude, Ornamental Horticulture Nursery, The University of Agriculture, Peshawar, Pakistan. Where altitude above sea level is $350-\mathrm{m}$. Semiarid climate exist in this location, where average annual rainfall is low (300 to $500 \mathrm{~mm}$ ), $60-70 \%$ rainfall occurs in summer, likewise $30-40 \%$ rainfall occurs in winter and maximum wind speed is $35 \mathrm{~km} / \mathrm{h}[\mathbf{3 1}, \mathbf{3 2}]$.

\section{Experimental design}

Experiment was run in one of the basic design i.e. Randomized Complete Block Design (RCBD) with split-plots arrangement which was repeated three times, eight treatments were assigned to each replicate. Whole experimental plot was divided into six main plots each having $12 \mathrm{~m}^{2}$ of area and consisting of four subplots. Eight plants were transplanted to each subplot. Total numbers of plants per replication were 64 . Organic manures (Farm yard manure at $25+$ Spent mushroom compost at $10+$ Poultry manure at 5 tons $\mathrm{ha}^{-1}$ ) and inorganic fertilizers (N:100, P:50, K:50 kg ha ${ }^{-1}$ ) were incorporated into the main plots whereas, cultivars such as Namli-F1, BlackBoy-F1, BSS-513 and Meiyinqienquan were kept in the subplots.

\section{Analysis of soil}

Before fertilizer application and transplantation, five composite samples of soil were taken at random with an auger at $0-30 \mathrm{~cm}$ depths from the whole area of experimental plot, to ascertain few physicochemical parameters of soil. Samples of soil were filled in plastic bags, labeled and then analyzed for physico-chemical properties such as soil texture, EC, $\mathrm{pH}, \%$ lime, \% Organic matter, $\% \mathrm{~N}$ and $\mathrm{P}, \mathrm{K}$ contents (Table 1).

\section{Analysis of organic materials}

Manure samples were collected and tested for N, P and K contents in the Soil Science Laboratory, Department of Soil \& Environmental Science at The University of Agriculture, Peshawar. The table 2 shows percentage of nutrients present in different manures.

\section{Nursery raisings}

First the nursery of four eggplant cultivars was raised. Seeds were sown on $3^{\text {rd }}$ March 2015 in pots containing a mixture of canal silt, well rotten FYM plus garden soil at $1: 1: 1$ and was irrigated with sprinkler regularly till germination. The seedlings 
were ready for transplantation within four weeks of sowing, attaining a height of $15 \mathrm{~cm}$ with 3-4 true compound leaves into the wellprepared field on raised ridges.

Table 1. Physicochemical properties of experimental plot before transplantation

\begin{tabular}{|c|c|}
\hline Soil variables & Values \\
\hline Textural class & Silty loam \\
\hline $\mathrm{pH}$ & 7.65 \\
\hline $\mathrm{EC}\left(\mu \mathrm{s} \mathrm{cm}^{-1}\right)$ & 0.18 \\
\hline$\%$ Lime & 9.26 \\
\hline$\%$ Organic matter & 0.28 \\
\hline$\left.\% \mathrm{~N}^{-1}\right)$ & 0.32 \\
\hline $\mathrm{P}\left(\mathrm{mg} \mathrm{kg} \mathrm{go}^{-1}\right)$ & 2.90 \\
\hline $\mathrm{K}^{+}\left(\mathrm{mg} \mathrm{kg}^{2}\right.$ & 95.0 \\
\hline
\end{tabular}

Table 2. Composition of nutrients in manures, under organic regime

\begin{tabular}{|c|c|c|c|}
\hline Organic regime Manures & $\mathbf{\% N}$ & $\mathbf{\%}_{\mathbf{2}} \mathbf{O}_{\mathbf{5}}$ & $\mathbf{\%} \mathbf{K}_{\mathbf{2}} \mathbf{O}$ \\
\hline Farm yard manure & 0.66 & 0.32 & 0.93 \\
\hline Spent mushroom compost & 0.47 & 0.23 & 0.85 \\
\hline Poultry manure & 0.62 & 0.31 & 0.83 \\
\hline
\end{tabular}

Field bed preparation and transplanting of seedlings

The field bed was thoroughly ploughed three times before transplanting. Manure used were FYM, spent mushroom compost and poultry manure incorporated at the rate of 25, 10 and 5tons ha $^{-1}$ into organic plots 30 days before transplantation, while NPK sources applied were Urea, Di ammonium phosphate and Muraite of Potash at 100:50:50 $\mathrm{kg} \mathrm{ha}^{-1}$ respectively into inorganic plots which were mixed into the soil prior to transplanting of seedlings except Urea of which half dose was applied before transplantation, while half dose after 40 days. The seedlings were transplanted on $10^{\text {th }}$ April 2015 into the field bed with plant and row spacing of 50 and $75 \mathrm{~cm}$, respectively. Mainly cultural practices i.e. hoeing, irrigation and weeding were carried out equally throughout the experimental work. However, field was flood irrigated at 7 to 10 days of interval, while fruits were picked after every 6 to 7 days. Bamboo sticks were used to support eggplant at $1^{\text {st }}$ fruiting stage which remained till the end of the crop. The crop was uprooted on $10^{\text {th }}$ November 2015.

Numbers of leaves per plant were counted from randomly selected tagged plants in each subplot at the time of first blooming stage and at the end of the crop, and their average was computed. Plant height $(\mathrm{cm})$ of five already tagged plants in each treatment was measured from ground level to the tip of the main stem by a measuring tape after the final harvest and mean value was taken. Data on number of days to $50 \%$ flowering were calculated from the date of transplantation to the fifty percent flowering in each tagged plant from the selected five plants randomly in each subplot and their average were then calculated. Fruit number per plant data was recorded by counting the total number of fruits in randomly selected five plants in each subplot, in every picking and then average of all pickings were calculated. Weight of the fruit plant ${ }^{-1}(\mathrm{~kg})$ was noted by adding the weight of all the fruits from each tagged plant collected at every picking until final picking in each treatment and their average was taken[33]. Fruit weight was taken by a sensitive weight 
balance [34] in grams (gm) and then changed into kilogram $(\mathrm{kg})$. From all the pickings of each cultivar, total yield was calculated on the basis of yield plot $^{-1}(\mathrm{~kg})$ then converted into tons ha ${ }^{-1}$ [35] by using the given formula;

Total yield $=\frac{\text { Yield } \text { per } \text { plot }}{\text { Plot } \text { area }} \times 10,000$

Chlorophyll content $\left(\mathrm{mg} \mathrm{cm}^{-2}\right)$ in the leaves of eggplant were determined with the help of SPAD meter. Five leaves of various sized were selected randomly from each tagged plant per treatment and their average was recorded [4]. Dry matter content (\%) in eggplant fruits were determined by heat dry method. Fruits were collected randomly from five tagged plants in each treatment. Thin slices of $10 \mathrm{gm}$ sample from each fruit was taken in Petri dishes and weighed. Samples were then placed in oven for 4 hours at $105^{\circ} \mathrm{C}$. After dryness, samples were weighed again and their average was computed [36]. Total soluble solids ( $\left.{ }^{0} \mathrm{Brix}\right)$ in eggplant fruits were recorded with the help of Hand Refractometer (Kernco, Instrument Co. Texas) by collecting fruit samples randomly from already tagged plants in each treatment and mean was observed. Eggplant fruit juice was squeezed on smooth clear glass prism of the refractometer. Readings were noticed by adjusting eye piece with rotation. Prism glass was rinsed with water and cleaned with a tissue paper for every next reading [37].

\section{Statistical analysis}

Data pertaining pre and post-harvest attributes of eggplant were analyzed statistically, using Randomized Complete Block Design with split-plot arrangement. Analysis of variances were computed by applying statistical computer software (Statistix 8.1) as described by [38] whereas, LSD (least significant difference) test was used to equate treatment means at $\mathrm{P} \leq 0.05$ significance level.

\section{Results and discussion \\ Number of leaves plant ${ }^{-1}$}

Recorded data for number of leaves plant $^{-1}$ is indicated in (Figure 1), corresponding ANOVA in (Table 3). From ANOVA table, it is obviously evident that there exist a highly significant difference among cultivars, growing regimes and their interaction at $(\mathrm{p} \leq 0.05)$ for number of leaves plant $^{-1}$. The interaction between cultivars and regimes (Fig-I) indicated that highest number of leaves were found in cultivar Namli-F1 (256.67) under inorganic regime, while minimum number (138.33) of leaves plant $^{-1}$ were recorded in Meiyinqienquan cultivar when grown under organic regime condition.

More number of leaves in cultivar Namli-F1 could be because of more number of leaf buds, more nutrients uptake, and climatic adaptability. More number of leaves under inorganic regime might be due to major role played by nitrogen in enzymes, chlorophyll and protein synthesis which ultimately boosted plants vegetative growth. [39] observed highest number of leaves in eggplant by increasing rates of nitrogen from 100 to $150 \mathrm{~kg} \mathrm{ha}^{-1}$. However, the increased in the number of leaves by all cultivars under both organic and inorganic regimes could be due to higher availability of nutrients under organic, while higher available nitrogen content under inorganic regime that helped in plants vegetative growth and development. Moreover, [40] also observed similar results that number of leaves in eggplant were considerably increased by using both organic as well as mineral fertilizers. In sweet pepper number of leaves plant ${ }^{-1}$ were significantly improved by using nitrogen in the form of organic or inorganic fertilizers [41]. Many researchers $[42,43,44]$ in pepper reported their results which are in agreement with the observations of the present study. 


\section{Plant height (cm)}

The data pertaining to plant height of brinjal cultivars is given in (Table 4). Its analysis of various (ANOVA) for plant height $(\mathrm{cm})$ is specified in (Table 3). The statistical analysis of respective mean data showed that among all the cultivars and regimes (organic and inorganic) there were significant differences, while interaction of both the treatments was found to be non-significant $(p \leq 0.05)$. Analyzed data for the regime showed that under the organic growth condition maximum plant height $179.28 \mathrm{~cm}$ was observed, while minimum plant length $172.27 \mathrm{~cm}$ was noted under inorganic regime. Among cultivars, maximum plant height $(198.65 \mathrm{~cm})$ was recorded in cultivar BSS-513 which was significantly different from other cultivars viz; Namli-F1, Meiyinqienquan and Black boy-F1 in which minimum plant height (171.79, 167.29 and $165.42 \mathrm{~cm}$, respectively) was recorded which were statistically at par with one another.

The increase in plant height in cultivar BSS513 could be due to its genetic makeup, as plant height is a gene controlling character which varies from specie to specie. In organic condition, maximum plant height may be because of optimum root growth and proliferation, absorbing more nutrients uptake that caused cell expansion, multiplication and elongation in the body of plant which ultimately increased height of the plant. Moreover, increased in plant height due to manure might be because of the availability of more micro and macro nutrients which were released on the decomposition of manures and also improves soil chemical and physical properties that lead to increased plant height [45]. Plant height of chilli and okra were significantly improved due to application of Azospirillum inoculums at $2.50 \mathrm{~kg} \mathrm{ha}^{-1}$ as compared to control condition [46]. Current results are in line with the conclusion of [47] who observed tomato grown at correct time on poultry manure performed superior in term of plant height. Similarly, [48] in maize and [49] in potato also noticed maximum plant height under the organic conditions.

Table 3. ANOVA for the influence of Organic and Inorganic regimes on various attributes of brinjal cultivars.

\begin{tabular}{|c|c|c|c|}
\hline Characters & Cultivars (C) & Regimes (R) & Interaction C $\times \mathbf{R}$ \\
\hline No of leaves plant $^{-1}$ & $* *$ & $*$ & $* *$ \\
\hline Plant height & $*$ & $*$ & Ns \\
\hline No of days to 50\% flowering & $* *$ & $*$ & Ns \\
\hline No of fruits plant $^{-1}$ & $* *$ & $*$ & $*$ \\
\hline Fruit weight plant $^{-1}$ & $*$ & $*$ & $*$ \\
\hline Total yield & $*$ & $*$ & Ns \\
\hline Chlorophyll content & $\mathrm{ns}$ & $*$ & Ns \\
\hline Fruit dry matter content & $*$ & Ns & Ns \\
\hline Total soluble solids & $* *$ & $*$ & Rs \\
\hline
\end{tabular}

$\mathrm{Ns}, *, * *$ stands for non-significant, significant and highly significant at $\mathrm{p} \leq 0.05$ level of significance respectively 
Table 4. Plant height, Days to $50 \%$ flowering, Chlorophyll content, Fruit dry matter content and Total soluble solids of eggplant cultivars under organic and inorganic regime

\begin{tabular}{|c|c|c|c|c|c|}
\hline Characters & $\begin{array}{l}\text { Plant height } \\
\text { (cm) }\end{array}$ & $\begin{array}{c}\text { Days to } 50 \% \\
\text { flowering }\end{array}$ & $\begin{array}{c}\text { Chlorophyll } \\
\text { content }\left(\mathrm{mg} \mathrm{cm}^{-2}\right)\end{array}$ & $\begin{array}{l}\text { Fruit dry matter } \\
\text { content }(\%)\end{array}$ & $\begin{array}{c}\text { TSS } \\
\left(\text { Brix }^{0}\right)\end{array}$ \\
\hline Treatments & & Cultivars (C) & & & \\
\hline Namli-F1 & $171.79 \mathrm{~b}$ & $35.17 \mathrm{c}$ & 0.039 & $7.88 \mathrm{a}$ & $2.45 \mathrm{~b}$ \\
\hline Black boy-F1 & $165.42 \mathrm{~b}$ & $38.42 \mathrm{~b}$ & 0.044 & $7.91 \mathrm{a}$ & $3.22 \mathrm{a}$ \\
\hline BSS-513 & $198.67 \mathrm{a}$ & $38.58 \mathrm{~b}$ & 0.043 & $8.26 \mathrm{a}$ & $2.03 \mathrm{c}$ \\
\hline Meiyinqienquan & $167.24 \mathrm{~b}$ & $41.68 \mathrm{a}$ & 0.041 & $6.15 \mathrm{~b}$ & $2.23 \mathrm{bc}$ \\
\hline LSD & 13.8 & 1.95 & -- & 1.24 & 0.39 \\
\hline & & Regimes (R) & & & \\
\hline Organic & $179.28 \mathrm{a}$ & $37.38 \mathrm{~b}$ & $0.041 \mathrm{~b}$ & 7.11 & $2.65 \mathrm{a}$ \\
\hline Inorganic & $172.27 \mathrm{~b}$ & $39.55 \mathrm{a}$ & $0.043 \mathrm{a}$ & 7.99 & $2.32 \mathrm{~b}$ \\
\hline & & Interaction & & & \\
\hline $\mathrm{C} \times \mathrm{R}$ & NS & NS & NS & NS & NS \\
\hline LSD & NS & NS & NS & NS & NS \\
\hline
\end{tabular}

*Mean values followed by different letters are significantly different $(\mathrm{p} \leq 0.05)$ according to LSD test. NS: Nonsignificant

\section{Number of days to $50 \%$ flowering}

In (Table 4) shows data regarding the mean of number of days to $50 \%$ flowering of brinjal cultivars while its analysis of variance (ANOVA) in Table 01. ANOVA (Table 3) showed significant differences among cultivars and regimes $(\mathrm{P} \leq 0.05)$, while their interaction for number of flowering was found non-significant. Mean value for regimes (Table 02) revealed that minimum days to $50 \%$ flowering (37.38) were recorded by plants grown in organic regime, while more number of days to flowering (39.55) was taken by inorganic regime.

Observing the mean values for number of days to $50 \%$ flowering (Table 4) of cultivars, Namli-F1 was earliest to flower took 35.17 days, followed by Black boy-F1 (38.42) and BSS-513 (38.52) which were statistically akin, while cultivar Meiyinqienquan took maximum days (41.68) to $50 \%$ flowering. Induction of early flowering in cultivar Namli-F1 may be because of its genetic potential, which has a significant role in plants vegetative and reproductive phase. Under organic regime early flowering by all the cultivars might be due to most of the beneficial nutrients availability, thus high uptake by plants that produced more photoasimilates which were essential for induction of flowering [50].

The present findings are similar with [51] who stated that the least number of days to flowering was taken by eggplant when grown under FYM + Poultry manure. Organic fertilizers application in tomato have significant influence on days to early flowering [52]. [53]suggested that basal application of PM resulted in early flowering in chilies compared with control treatment. Moreover, [54] evaluated that eggplant fertilized with $125 \%$ recommended dose of fertilizers cause delayed in flowering that might be the presence of high nitrogen contents which produced excessive vegetative growth that delayed flower initiation. [55] in eggplant and [56] in tomato also reported the same results.

Number of fruits plant $^{-1}$

In (Figure 2) shows the data concerning number of fruits plant $^{-1}$, while the table 01 
shows its analysis of variance. The ANOVA for number of fruits plant $^{-1}$ showed that there were significant differences among cultivars, growing regimes and their interaction at $p \leq 0.05$. In (Figure 2), the interaction among regimes and cultivars showed that highest number of fruits (37.58) were produced by Namli-F1 grown under organic regime, while lowest number of fruits plant ${ }^{-1}$ (6.08) were produced under the inorganic regime for cultivar Meiyinqienquan.

Reason for the more number of fruits plant ${ }^{-1}$ in Namli-F1 cultivar could be the more number of lateral branches and leaves plant ${ }^{-1}$ that produced more number of flowers which resulted in increasing fruit number. Increasing the number of fruits plant ${ }^{-1}$ by all cultivars using organic manure might be due to slow release of essential nutrients that resulted in more number of flower buds which ultimately produced more number of fruits plant $^{-1}$. The results regarding this variable are in harmony with the observation of [34] who suggested that application of 30 $\mathrm{t} \mathrm{ha}^{-1}$ of organic manure in single and splitsplit give more number of fruits plant $^{-1}$. Similar results were also suggested by [57, 58] in eggplant while [46] in chili that organic manures application resulted in increased number of fruits plant ${ }^{-1}$. The reduction in number of fruits in brinjal under inorganic regime could be due to presence of higher amount of nitrogen which is closely linked with vigorous vegetative growth which delayed the appearance of flower buds that ultimately lead toward the decline in number of fruits [52].

Fruit weight plant $^{-\mathbf{1}}(\mathbf{k g})$

Mean data pertaining fruit weight plant $^{-1}$ for eggplant cultivars and both organic and inorganic regimes is indicated in (Figure 3). Analysis of variance of fruit weight plant $^{-1}$ is given in Table 01 which showed that eggplant cultivars, regimes both organic and inorganic and their interaction significantly $(p \leq 0.05)$ affected fruit weight plant $^{-1}$. The interaction between cultivars and regimes (fig III) indicated that highest fruit weight plant $^{-1}$ was noted in cultivar Namli-F1 (3.19 $\mathrm{kg}$ ) under organic regime and lowest fruit weight was recorded under inorganic regime in cultivar Meiyinqienquan $(2.20 \mathrm{~kg})$.

Maximum fruit weight plant $^{-1}(\mathrm{~kg})$ was observed in Namli-F1 which might be attributed to more number of fruits per plant or high nutrients uptake by the plant. Better efficiency of organic regime in increasing fruit weight plant $^{-1}(\mathrm{~kg})$ could be the fact that FYM in organic manures supplied most of the micro-nutrients $(\mathrm{Mg}, \mathrm{Cu}, \mathrm{Zn}, \mathrm{Fe}$, and $\mathrm{Mn}$ ) and NPK in an optimum level which improved the nutrient grading and water holding ability of soil [25]. The results of present investigation are comparable with the results of [34] observed that maximum fruit weight in eggplant could be due to the improved physical characteristics of soil by the use of organic manure that supply nutrients to the soil for the uptake by plants for storage. Results are also supported by the investigation of [59] in eggplant and [48] in maize where fruit weight enhanced due to application of organic fertilizers.

\section{Total yield (tons ha-1)}

In (Figure 4), revealed the results of total yield of eggplant cultivars, (Table 3 ) shows its ANOVA. The analysis of variance indicated that cultivars, regimes and their interaction significantly $(\mathrm{p} \leq 0.05)$ affected total yield of eggplant. The interaction between eggplant cultivars and regimes both organic and inorganic declared that under organic condition highest (78.96 tons ha ${ }^{-1}$ ) fruit yield was observed in Namli-F1, whereas in Meiyinqienquan minimum (58.29 tons ha $^{-1}$ ) fruit yield was recorded under inorganic regime (Figure 4).

The increased in fruit yield (tons $\mathrm{ha}^{-1}$ ) in cultivar Namli-F1 could be due to maximum fruit number and weight plant ${ }^{-1}$ or higher adoptability to the environmental condition. 
The higher yield response by all cultivars under organic regime may be due to balanced $\mathrm{C}$ : $\mathrm{N}$ ratio that contributed to increase synthesis of photosynthates [60]. Organic manures also increase water holding and cation exchange capacity of soil [61], leading to enhancement in fruit yield. Minimum fruit yield under inorganic regime promoted excessive vegetative growth (no of leaves plant ${ }^{-1}$ ) that may reduce crop resistance to physiological disorders, diseases and pests $[62,63]$.
Results are also matched with the observations of [59] that eggplant yield was enhanced significantly through the integrated use of organic manure. Similarly, increased yield in brinjal by the addition of organic manure could be attributed to supply of important micronutrients that helped in plant's metabolic activity through their early vigorous growth [64]. Results of many other researchers [65] in okra; [55] in eggplant also coincide with the conclusion of the present work.

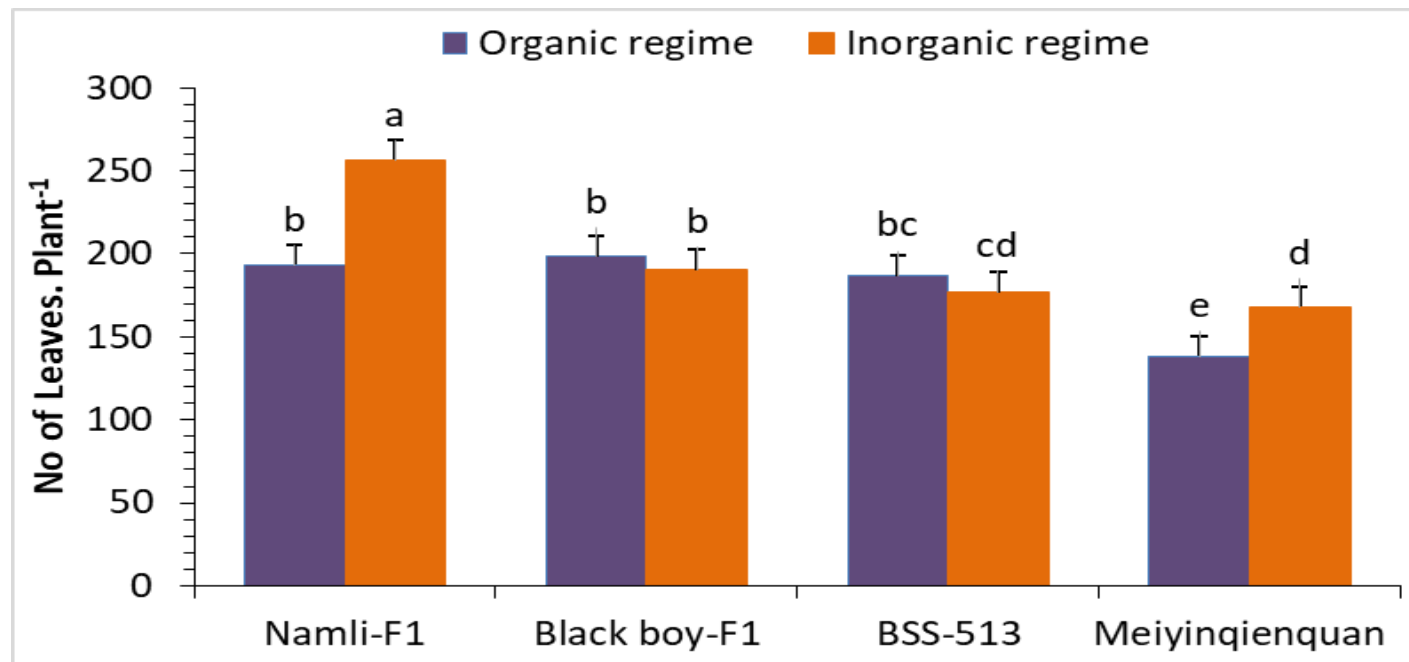

Figure 1. Interaction effect of cultivars and regimes on number of leaves plant ${ }^{-1}$

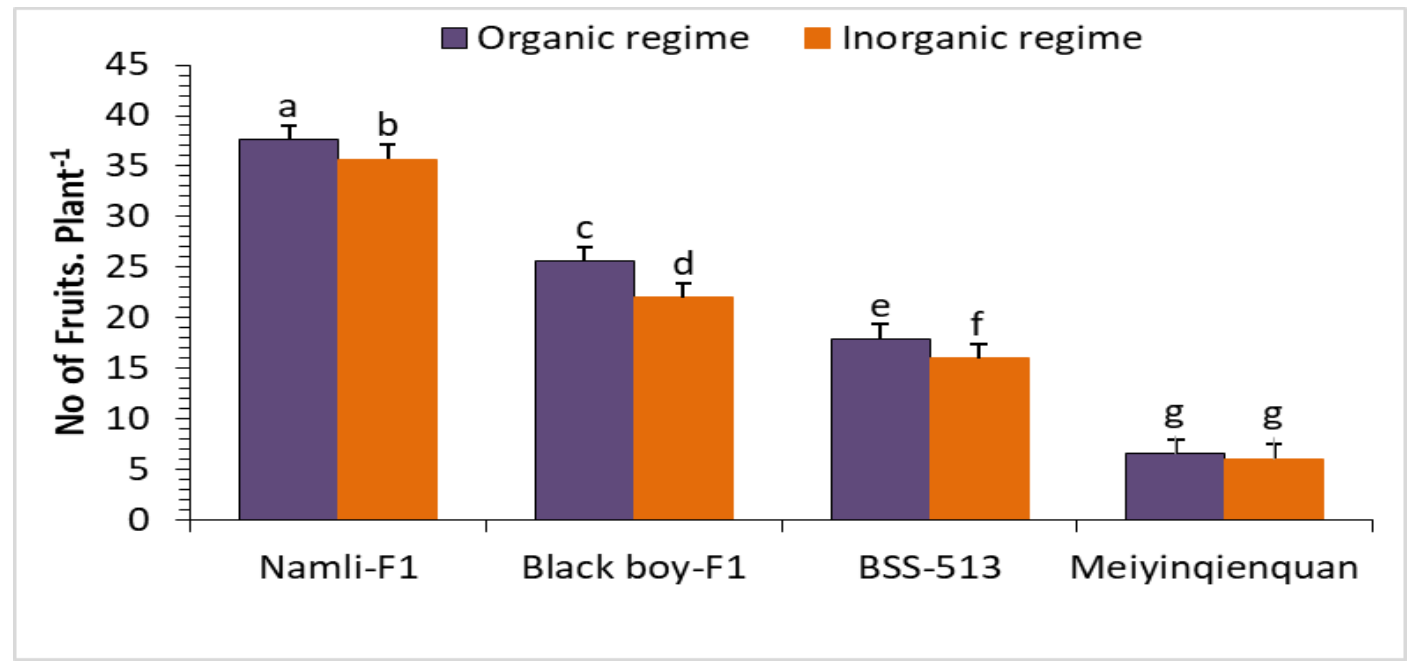

Figure 2. Interaction effect of cultivars and regimes on number of fruits plant ${ }^{-1}$ 


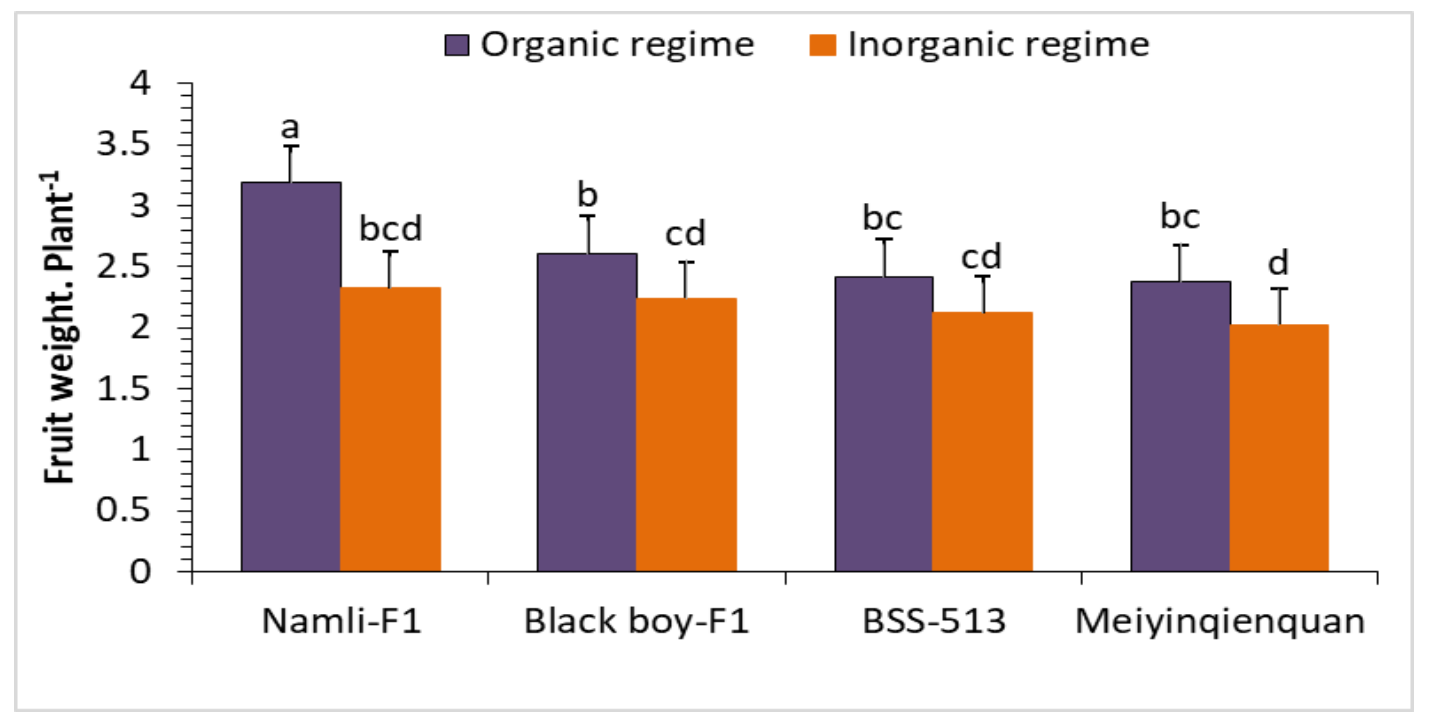

Figure 3. Interaction effect of cultivars and regimes on fruit weight plant ${ }^{-1}$

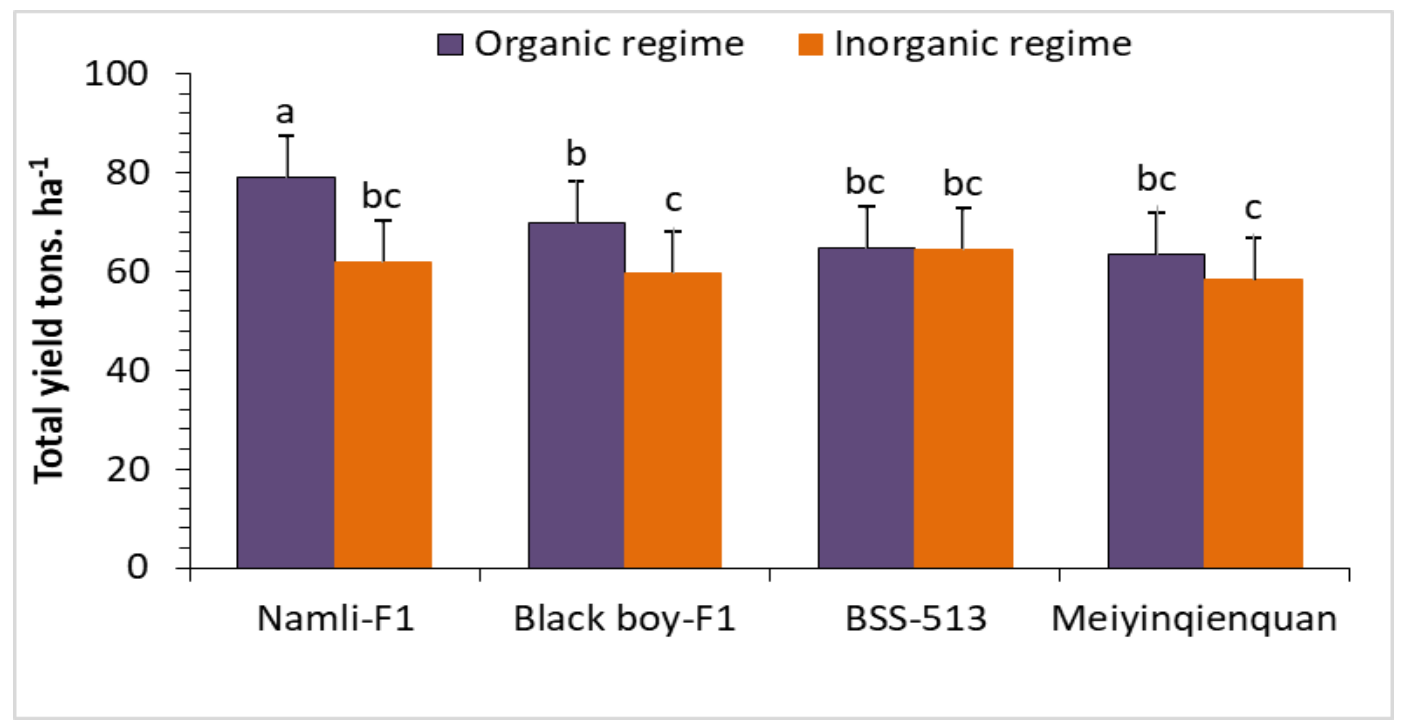

Figure 4. Interaction effect of cultivars and regimes on total yield tons. ha-1

Chlorophyll content $\left(\mathbf{m g} / \mathrm{cm}^{2}\right)$

Data regarding the chlorophyll content has been illustrated in (Table 4) while its ANOVA in table 01. The ANOVA table indicated that there is a significant difference between regimes only at $\mathrm{p} \leq 5 \%$. Mean values of chlorophyll content for regimes showed that highest chlorophyll content i.e. $0.043 \mathrm{mg} / \mathrm{cm}^{2}$ were observed under the inorganic regime while lowest
$0.041 \mathrm{mg} / \mathrm{cm}^{2}$ were calculated under organic regime.

More chlorophyll content under inorganic regime might be attributed due the availability of more nitrogen provided by the inorganic fertilizers. [66] opined that Nitrogen is one of the basic component of all proteins (amino acids) and lipids thus acting as one of the structural compound of chloroplast. Our results are resemblance with those reported by [41] who detected 
that all growth characters were increased in sweet pepper with the use of inorganic fertilizers that caused a positive effect on chlorophyll contents.

\section{Fruit dry matter content (\%)}

Analyzed data for the fruit dry matter content (\%) is presented in (Table 4), corresponding ANOVA is shown in Table 01. Analysis of variance explains that for the fruit dry matter content, a significant difference among cultivars, while nonsignificant variations in regimes and their interaction at $p \leq 5 \%$ were observed (Table $3)$. Mean values regarding fruit dry matter (\%) for different cultivars revealed highest fruit dry matter in cultivar BSS-513 (8.26 $\%)$, that was statistically at par (7.91 \%) with Black boy-F1 cultivar and Namli-F1 (7.88 \%), while minimum fruit dry matter content $(6.15 \%)$ was recorded in cultivar Meiyinqienquan (Table 4). Enhancement in the fruit dry matter in cultivar BSS-513, Black boy-F1 and Namli-F1 might be due to the highest fruit fresh weight $(\mathrm{kg})$, total soluble solids $\left(\mathrm{Brix}^{0}\right)$ and low moisture content in these cultivars. Present conclusion is supported by the findings of [67] who distinguished a significant distinctive trait in the fruit dry matter content of the eggplant among its cultivars.

\section{Total soluble solids (Brix ${ }^{\mathbf{}}$ )}

Concerned mean data for total soluble solids $\left(\right.$ Brix $\left.^{0}\right)$ is given in (Table 4), whereas its ANOVA is revealed in (Table 3). The analyzed variations among means in Table (01) indicated that total soluble solids $\left(\right.$ Brix $\left.^{0}\right)$ was affected significantly by both regimes and cultivars however, their interaction was recorded non- significant at $(\mathrm{p} \leq 0.05)$ level of significance. Mean value (Table 02) of total soluble solids for the growing regimes depicted that more total soluble solids (2.65 Brix $^{0}$ ) was observed in plants grown under organic condition whereas least amount of total soluble solids $\left(2.32 \mathrm{Brix}^{0}\right)$ was recorded under inorganic regime.

In (Table 4) also indicated a highly significant variation among different cultivars for total soluble solids, in which more total soluble solids $\left(3.22\right.$ Brix $\left.^{0}\right)$ was recorded in Black boy $F 1$, followed by Namli F1 in which 2.45 Brix $^{0}$ was observed, closely followed by Meiyinqienquan (2.23 Brix $^{0}$ ), while in cultivar BSS-513 less TSS (2.03 Brix $^{0}$ ) was recorded. The superiority of cultivar Black boy-F1 in the total soluble solids $\left(\right.$ Brix $\left.^{0}\right)$ may be due to some physiological changes in the fruit such as hydrolysis of polysaccharides of the fruit cell wall [68], breakdown of starch into sugar [69].

The reason for the higher content of TSS $\left(\right.$ Brix $\left.^{0}\right)$ under organic regime might be the release of optimum concentration of available nitrogen from organic fertilizers into root zone of the plant which promoted the activity of protein synthesis, cell division and enlargement as well as photosynthetic process which ultimately enhanced total soluble solids $\left(\right.$ Brix $\left.^{0}\right)$. Using organic fertilizers (Bio-fertilizers) for sweet pepper caused an increment in the total soluble solid in the fruits [41]. Furthermore, findings of [70] are in harmony with the present study who noticed that organic fertilization have a positive influence on the total soluble solids $\left(\mathrm{Brix}^{0}\right)$ of bell pepper fruit. Previous other results also supported the present study such as $[71,72]$ in pepper fruit, while $[11]$ in eggplant.

\section{Conclusion}

In light of the results achieved through this particular experimental work, it has been concluded that Cultivar Namli-F1 leads to enhancement in yield, resulted in maximum number of leaves, fruits, fruit weight plant $^{-1}$, total yield closely followed by Black boyF1. Qualitative characters including total soluble solids were noticed maximum in cultivar Black boy-F1 and fruit dry matter 
content were proved to be superior in cultivar BSS-513. Whereas, the performance of cultivar Meiyinqienquan was inferior among all cultivars. For the better yield and Authors' contributions

Conceived and designed the experiments: $\mathrm{U}$ Shahid, K Shah \& I Ahmed, Performed the experiments: U Shahid, G Ara, SI Khan \& B Zainub, Analyzed the data: K Shah, U Shahid, G Ara \& G Guttai, Contributed reagents/ materials/ analysis tools: NU Amin \& I Ahmed, Wrote the paper: K Shah \& U Shahid.

\section{References}

1. Kantharajah AS \& Golegaonkar PG (2004). Somatic embryogenesis in eggplant Review. J Sci Hortic 99: 107-117.

2. Onyenuga VA \& Fetuga BI (1975). Dietary importance of fruits and vegetables. Proceedings of the 11th National Seminaron Fruits and Vegetables, Ibadan, pp. 12-13.

3. Kandoliya UK, Bajaniya VK, Bhadja NK, Bodar NP \& Golakiya BA (2015). Antioxidant and nutritional components of eggplant (Solanum melongena L.) fruit grown in Saurastraregion. Inter $J$ Curr Microbiol App Sci 4(2): 806-813.

4. Latha P, Jeyaraman S \& Prabakaran R (2014). Effect of microbial and chemical fertilizer one eggplant (Solanum melongena L.) C. Var CO-2. Inter J Pure Appl Bio Sci 2(4): 119-124.

5. Doifode VD \& Nandkar PB (2014). Influence of Biofertilizers on the Growth, Yield and Quality of Brinjal Crop. Inter J Life Sci A2: 17-20.

6. Sihachkr D, Chaput MH, Serraf L \& Ducreux G (1993). Regeneration of plants from protoplasts of eggplant (Solanum melongena L.). In: Bajaj, Y.P.S. (Ed.), Biotechnology in Agriculture and Forestry, Plant Protoplasts and Genetic Engineering. Springer, Berlin, pp. 108-122.

7. MINFAL (2013). Agricultural Statistics of Pakistan. Ministry for Food, Agric \& Livest. Govt. of Pakistan.

8. Chaudhary P \& Kumar S (2014). Variability, heritability and genetic advance qualitative attributes of eggplant cultivars, organic regime showed superiority over the inorganic regime.

studies in eggplant (solanum melongena L.). Plant Archives 14(1): 483-486.

9. Whitaker BD \& Sommel JR (2003). Distribution of hydroxylecinnamic acid conjugates in fruit of commercial eggplant (Solanum melongena L.) cultivar. J Agric Food Chem 51(11): 3448-3454.

10. Kalawate A \& Dethe MD (2007). Bioefficacy study of biorational insecticide on brinjal. J. Biopest 5(1): 75-80.

11. Kashyap S, Kumar S, Maji S \& Kumar D (2014). Effect of organic manures and inorganic fertilizers on growth, yield and quality of brinjal (Solanum melongena L.) cv. Pant Rituraj. Inter J Agric Sci 10(1): 305-308.

12. Abbas MA, Elamin SDM \& Elamin EAM (2011). Effects of chicken manure as component of organic production on yield and quality of eggplant (Solanum melongena L.) fruits. J Sci Tec 12(4): pp.8.

13. Balliu A, Sallaku G \& Kuci S (2008). Nitrogen concentration in nutrient solution and module volume effects on the growth characters and yield potentials of eggplant seedlings. J Acta Hort 801: 1373-1377.

14. Basela O \& Mahadeen A (2008). Effect of fertilizers on growth, yield, yield components, quality and certain nutrient contents in broccoli (Brassica oleracea L.). Inter J Agric Biol 10(6): 627-632.

15. Sat P \& Saimbhi MS (2003). Effect of varying levels of nitrogen and phosphorus on earliness and yield of brinjal hybrids. $J$ Res Crops 4(2): 217-222.

16. Hafez MM \& Mahmoud AR (2004). Response of snap bean (Phaseolus vulgaris L.) to nitrogen fertilizer source. Anal Agric Sci Mashtohor 42(1): 261-270.

17. Rahim M (2002). Cultivation of wheat and its uses. City press, Dhaka pp. 10-12.

18. Thorup RM (1984). A practical guide to soil fertility and Fertilizer Use. Handbook of Ortho Agronomy. Fertilizer Division Chevron Chemical company, pp. 115-117. 
19. Devlin RM \& Witham FH (1986). Plant Physiology. CBS publishers and distributors 485, Jain Bhawan Shadhara, $\left(4^{\text {th }}\right.$ Ed) Delhi, India.

20. Ghasem S, Morteza AS \& Maryam $T$ (2014). Effect of organic fertilizers on cucumber (Cucumis sativus) yield. Inter J Agri Crop Sci 7(11): 808-814.

21. Tonfack LB, Bernadac A, Youmbi E, Mbouapouognigni VP, Ngueguim M \& Akoa A (2009). Impact of organic and inorganic fertilizers on tomato vigor, yield and fruit composition under tropical andosol soil conditions. J Fruits 64: 167177.

22. Gulshan AB, Saeed HM, Javid S, Meryem T, Atta MI \& Amin-ud-Din M (2013). Effect of animal manure on the growth and development of okra (Abelmoschus esculentus L.). J Biol Sci 8(3): 1990-6145.

23. Makinde EA, Ayoola OT \& Akande MO (2007). Effects of organo-mineral fertilizer application on the growth and yield of Egusi melon. Australian J. Basic Appl. Sci 1: 15-19.

24. Belay A, Classens AS, Wehner FC, De Beer JM (2001). Influence of residual manure on selected nutrient elements and microbial composition of soil under long term crop rotation. S Afr J Plant Soil 18: 16.

25. Hussein TO (1997). Effect of poultry manure on growth of tomato proceeding of 15 th annual conference. Hortson. NIHORT, Ibadan, Nigeria, pp 43-45.

26. Deksissa T, Short I \& Allen J (2008). Effect of soil amendment with compost on growth and water use efficiency of Amaranth. In: Proceedings of the UCOWR/NIWR annual conference: International water resources: challenges for the 21 st century and water resources education. Durham, NC.

27. Khalid AA, Tuffour HO, Bonsu M, AdjeiGyapong T, Abubakar A, Boateng IY, Melenya C \& Kpotor P (2014). Effects of Poultry Manure and NPK Fertilizer on Growth and Yield of Garden Eggs (Solanum Melongena) in a Sandy Soil in Ghana. Inter J Scientific Res Knowledge 2(6): 257-264.
28. Jordan SN, Mullen GJ \& Murphy MC (2008). Composition variability of spent mushroom compost in Ireland. J Bioresour Technol 99(2): 411-8.

29. Aliyu L, Karikari SK \& Ahmed MK (1992). Yield and yield components of eggplant (Solanum gilo L.) as affected by date of transplanting, intra-row spacing and nitrogen fertilization. J Agric Sci \& Tech 2(1): 7-12.

30. Singh AP, Luthria D, Wilson T, Vorsa N, Singh V, Banuelos GS \& Pasakdee S (2009). Polyphenols content and antioxidant capacity of eggplant pulp. Food Chem 114: 955-961.

31. Shah K, ul Amin N, Ahmad I \& Ara G (2018). Impact assessment of leaf pigments in selected landscape plants exposed to roadside dust. Environ Sci and Pollu Res 25(23): 23055-23073.

32. Shah K, Amin N, Ahmad I, Shah S \& Hussain K (2017). Dust particles induce stress, reduce various photosynthetic pigments and their derivatives in Ficus benjamina: a landscape plant. Inter J Agric Biol 19: 1469-1474.

33. Christo IE, Okorie HA \& Chikere NC (2011). Performance of eggplant (Solanum gilo L.) as affected by manure types and rates. Global Res J Sci 1: 43-47.

34. Agbo CU, Chukwudi PU \& Ogbu AN (2012). Effects of rates and frequency of application of organic manure on growth, yield and biochemical composition of Solanum melongena L. (cv. 'Ngwa local') fruits. J Ani \& Pl Sci 14(2): 1952-1960.

35. Oyewole CI, Akogu ES \& Attah ES (2014). Response of eggplant (Solanum melongena L.) to nutrient sources and rates of application: I. yield components and fruit yield. Inter J Agric Bio Sci 3(4): 166-172.

36. Paddaa MS, Amaranteb CVT, Garciac RM, Slaughterd DC \& Mitcham EJ (2011). Methods to analyze physico-chemical changes during mango ripening: Amultivariate approach. Postharvest Bio \& Tec 62: 267-274.

37. Iqbal $M$, Niamatullah $M$ \& Mohammad D (2012). Effect of different doses of nitrogen on economical yield and physio-chemical 
characteristics of apple fruits. $J$ Anil \& $P l$ Sci 22(1): 165-168.

38. Jandel Scientific (1991). Jandel Scientific Table Curve user's manual v.30 software. AISN Software, Corte Madera, California.

39. Aminifard $\mathrm{MH}$, Aroiee $\mathrm{H}$, Fatemi $\mathrm{H}$, Ameri A \& Karimpour S (2010). Responses of eggplant (Solanum melongena L.) to different rates of nitrogen under field conditions. J Cent Eurpn Agril 11(4): 453458.

40. Mona MA, Mahmoud AR, EL-Desuki M \& Rizk FA (2011). Yield and fruit quality of Eggplant as affected by organic and mineral fertilizers application. Res J Agricult \& Biol Sci 7(2): 196-202.

41. Fawzy ZF, El-Bassiony AM, Yunsheng L, Zhu O \& Ghoname AA (2012). Effect of mineral, organic and bio-N Fertilizers on growth, yield and fruit quality of sweet pepper. J Apld Sci Res 8(8): 3921-3933.

42. Awad EM (2002). Effect of compost and some bio-fertilizers on growth, yield and quality of potato crops (Solanum tubersum L.). J Agric Sci 27(8): 5525-5537.

43. Akande MO, Garnica M \& Mina JM (2007). Nitrogen fertiliser source effects on the growth and mineral nutrition of pepper (Capsicum annuum L.) and wheat (Triticum aestivum L.). J Sci Food \& Agri 87(11): 2099-2105.

44. Feng NJ, Zhong ZX, Hai YS, Yong C, LiLi S, Lan W \& Long WJ (2010). Effects of organic materials on the growth of pepper and amelioration of reservoir sediment. Chinese. J Eco-Agricul 18(2): 250-255.

45. Ali MB, Lakun HI, Abubakar W \& Mohammed YS (2014). Performance of tomato as influenced by organic manure and sowing date in Samaru, Zaria. Inter $J$ Agron \& Agril Res 5(5): 104-110.

46. Singh CK, John SA \& Jaiswal D (2014). Effect of organics on growth, yield and biochemical parameters of chilli (Capsicum annum L.). J Agric and Veter Sci 7(7): 2732.

47. Tiamiyu RA, Ahmed HG \& Muhammad AS (2012). Effect of sources of organic manure on growth and yield of okra (Abelmoschus esculentus L.) Moench) in
Sokoto, Nigeria. Nigerian J Bsic \& Apld Sci 20(3): 213-216.

48. Okoroafor IB, Okelola EO, Edeh ON, Emehute VC, Onu CN, Nwaneri TC \& Chinaka GI (2013). Effect of Organic Manure on the growth and yield performance of maize in Ishiagu, Ebonyi State, Nigeria. J Agric \& Vet Eri Sci 5(4): 28-31.

49. Abou-Hussein SD, Abou-Hadid AF, ElShorbagy T \& El-Behariy U (2003). Effect of cattle and chicken manure with or without mineral fertilizers on vegetative growth, chemical composition and yield of potato crops. J Acta Hort (ISHS) 608: 7379.

50. Sharma SK (1995). Seed production of tomato as influenced by nitrogen, phosphorous and potassium fertilization. Annals Agril Res 16: 399-400.

51. Waseem K, Hussain A, Jilani MS, Kiran M, Ghazanfarullah, Javeria S \& Hamid A (2013). Nutritional management in brinjal (Solanum melongena L.) using different growing media. Pak J Sci 65(1): 25.

52. Ibrahim KHM \& Fadni OAS (2013). Effect of organic fertilizers application on growth, yield and quality of tomatoes in North Kordofan (sandy soil) western Sudan. Greener. J Agril Sci 3(4): 299-304.

53. Ikeh AO, Ndaeyo NU, Uduak IG, Iwo GA, Ugbe LA, Udoh EI \& Effiong GS (2012). Growth and yield responses of pepper (Capsicum frutescens L.) to varied poultry manure rates in Uyo, southeastrn Nigeria Arpn. J Agri \& Biol Sci 7(9): ISSN 19906145.

54. Ndereyimana A, Praneetha S, Pugalendhi L, Pandian BJ \& Rukundo P (2013). Earliness and yield parameters of eggplant (Solanum melongena L.) grafts under different spacing and fertigation levels. Afri J Pl Sci 7(11): 543-547.

55. Suthar MR, Singh GP, Rana MK and Makhan L (2005). Growth and fruit yield of brinjal (Solanum melongena L.) as influenced by planting dates and fertility levels. J Crop Res 30(1): 77-79.

56. He W \& Chen D (1996). Effect of different levels of fertilizer application on growth of 
tomato seedlings grown in seedling trays. Beijing Agric Sci 4(2): 22-24.

57. Asiegbu JE \& Uzo FO (1984). Yield and yield components response of vegetable crops to farm yard manure rates in the presence of inorganic fertilizer. J Agric Pueterico 68: 243-252.

58. Devi HH, Maity TK, Paria NC \& Thapa U (2002). Response of brinjal to different sources of nitrogen. J Veg Sci 29(1): 45-47.

59. Vijaya KS \& Seethalakshmi S (2011). Response of Eggplant (Solanum melongena L.) To Integrated Nutrient Management Amended Soil. Inter J Scif \& Engr Res 2(8): 8 .

60. Nainawat R \& Bharadwaj N (2003). Effects of vermicompost, farm yard manure and chemical fertilisers on growth, yield and yield attributes of two cultivars of wheat. In: Agrawal, SK (Ed.), Environ Scenario for 21st Century. APH publ Corp, New Delhi, pp 273-281.

61. Leng B (2006). Effect of organic manure on soil temperature, early vegetative development in muskmelon and weed growth. Proc, National Agric Plastic Cong (22): 19-27.

62. Batal K, Bondari K, Granberry D \& Mullinix B (1994). Effects of source, rate, and frequency of nitrogen application on yield, marketable grades and rot incidence of sweet onion (Allium cepa L. cv. Granex33). J Hortic Sci, pp 69.

63. Everaarts A (1994). Nitrogen fertilization and head rot in broccoli. NJAS wageningen. J life Sci 42(3): 195-201.

64. Anburani A \& Manivannan K (2002). Effect of integrated nutrient management on growth in brinjal (Solanum melongena L.) cv. Annamalai. S Indian Horticul 50(46): 377-386.
65. Grey C \& William V (2006). The right away to grow fresh vegetable all year round. Macmillan publishers, London.

66. Arisha HM \& Bradisi A (1999). Effect of mineral fertilizers and organic fertilizers on growth, yield and quality of potato under sandy soil conditions. Zagazig J Agric Res 26: 391-405.

67. Raigon M, Rodriguez-Burruezo A \& Prohens J (2010). Effects of organic and conventional cultivation methods on composition of eggplant fruits. J Agric Food Chem 58(11): 6833-6840.

68. Crouch I (2003). 1-Methylcyclopropene (Smartfresh TM) as an alternative to modified atmosphere and controlled atmosphere storage of apples and pears. $J$ Acta Hort 600: 433-436.

69. Beaudry RM, Severson RF, Black CC \& Kays SJ (1989). Banana ripening: Implications of changes in glycolytic intermediate concentrations, glycolytic and gluconeogenic carbon flux, and fructose 2, 6-bisphosphate concentration. $J$ Plant Physiol 91: 1436-1444.

70. Shahein MM, Sayed SF, Hassan HA \& Abou-El-Hassan S (2015). Producing sweet pepper organically using different sources of organic fertilizers under plastic house conditions. Inter. Conference on Advances in Agricultural, Biol \& Enviro. Sci London (UK).

71. Amor F \& Del M (2007). Yield and fruit quality response of sweet pepper to organic and mineral fertilization. Renewable Agric and Food Sys 22(3): 233-238.

72. Arafa MM \& Shalabey OE (2007). Effect of zinc and organic manures on yield and fruit chemical composition of pepper plants grown on newly reclaimed soils. Anl Agril Sci (Cairo) 52(2): 441-450. 